\title{
Analysis of Preventive Maintenance and Breakdown Maintenance on Production Achievement in the Food Seasoning Industry
}

\author{
Ahmad Bahrudin ${ }^{1}$, Indra Setiawan ${ }^{2}$, Moh. Mawan Arifin ${ }^{1}$, Wahyu Inggar Fipiana ${ }^{1}$, Vivi Lusia ${ }^{1}$ \\ ${ }^{1}$ Industrial Engineering Department, Universitas Borobudur Jakarta \\ Jalan Raya Kalimalang No.1 Jakarta 13620 \\ ${ }^{2}$ Master of Industrial Engineering Program, Universitas Mercu Buana Jakarta \\ Jalan Meruya Selatan No.1 Kembangan Jakarta 11650 \\ email : indra.setiawan.2022@gmail.com \\ doi: https://doi.org/10.31315/opsi.v14i2.5540
}

Received: $6^{\text {th }}$ October 2021; Revised: $19^{\text {th }}$ November 2021; Accepted: $1^{\text {st }}$ December 2021;

Available online: $21^{\text {st }}$ December 2021; Published regularly: December 2021

\begin{abstract}
The machine is a facility that is necessary for the company in production. The machine can reduce the failure rate of the product and reach the target time according to the customer's request. Therefore the machine needs to be cared for and maintained. Maintenance and care is a way to prevent the machine from being damaged. This study aims to determine and analyze the effect of preventive maintenance and breakdown maintenance on production achievement. The research was conducted in the Food Seasoning Industry. The research population is maintenance employees and production employees. The sample used was 25 respondents based on employees who are experts in their fields. The analytical method used in this research is the descriptive analysis method with a quantitative approach with linear regression analysis. Data processing using the help of IBM Statistics 21.00 software. The results showed that preventive maintenance partially had a significant effect on production achievement. Breakdown maintenance partially has no significant effect on the achievement of production. Simultaneously preventive maintenance and breakdown maintenance have a significant effect on the achievement of production. Linear regression analysis resulted in the model formula $Y=9.004+0.561\left(X_{1}\right)+0.042\left(X_{2}\right)$
\end{abstract}

Keywords: breakdown maintenance; food seasoning industry; linear regression; preventive maintenance; production achievement

\section{INTRODUCTION}

All Rapid industrial development will lead to increased competition in the global market. To be able to compete, companies must maintain smooth production and increase production (Wang et al., 2020). One of the best ways is the company's efforts to extend the operating time of an industrial machine and maintain a smooth production process (Setiawan, 2021) (Basri et al., 2017). This requires a proper maintenance and care program (Liu \& Wu, 2018). Preventive maintenance and Breakdown maintenance are the best alternatives in solving these problems (Kumar \& Yogish, 2016) (Ben et al., 2021) (Sukma et al., 2021). Most of an industrial company does not consider the possibility of a sudden engine failure which has an impact on low production achievement (Sahrupi \& Juriantoro, 2018).
Preventive maintenance is maintenance and care activities carried out to prevent unexpected damage and find conditions or circumstances that can cause production facilities to be damaged (Ebrahimi et al., 2020) (Putri et al., 2020) (Sasitharan et al., 2020). While Breakdown Maintenance is maintenance carried out when the machine has been damaged so that the machine cannot operate normally/ the production process stops completely (Prabowo \& Adesta, 2019) (Mohideen \& Ramachandran, 2014). Both of these maintenance models can increase productivity and overall company production achievement if they are carried out properly and regularly (M.Méndez \& Rodriguez, 2017) (Er-Ratby \& Mabrouki, 2018) (Rizlan et al., 2018). Production achievement is the result of the production process or raw material processing activities, either in the form of raw materials or semi-finished materials into 
a product that has added value (Jasasila, 2017). Production achievement can also be referred to as the result of making an item so that its value can increase compared to the raw material (Shagluf \& Longstaff, 2014) (Situmorang et al., 2020).

Food Seasoning Industry is a company engaged in the manufacture of food seasonings that are guaranteed to be safe and halal products. In the production process, this company has several machines to support the production process. The machines are the Blending machine and Pin mill machine. A Blending machine is a machine that serves to stir or mix food raw materials in the form of flour or powder. While the Pin mill machine is a machine that functions as a product refiner from the form of dry grains or granules into flour form with a level of fineness that can be adjusted according to the filter used (Annasya, 2017). This company has implemented preventive maintenance and breakdown maintenance programs on production machines periodically, once a month. These activities are carried out at the end of each month and perform breakdown maintenance activities whenever the machine is damaged (Nursubiyantoro et al., 2016) (Sari \& Soepardi, 2018).

Based on initial observations, there are still some machines that suddenly fail even though they have been treated. In addition, the costs incurred in this treatment are quite large so that they are not following the set targets. In addition, production productivity is also not achieved. This resulted in the percentage of production achievement did not reach the target of $100 \%$. Data of production achievement in 2019 can be seen in Figure 1.

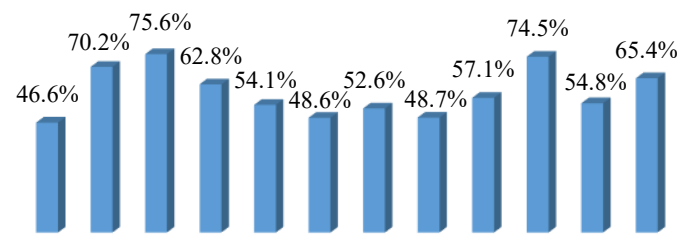

Jan Feb Mar Apr May Jun Jul Aug Sep Oct Nov Dec

$$
\text { Month }
$$

Figure 1. Percentage of production achievement in 2019
Based on these problems, it is necessary to evaluate the maintenance and maintenance activities of the machine on the achievement of production. The evaluation was carried out to find out the indicators that had a significant effect (Prabowo et al., 2018) (Iqbal, 2017) (Irawan et al., 2021). The purpose of this study was to determine the effect of preventive maintenance and breakdown maintenance on production achievement. Novelty in this research was conducted in the Food Seasoning Industry. The analysis of this influence test uses the linear regression method.

\section{METHODS}

This study uses a descriptive analysis method with a quantitative approach (Sugiyono, 2017). So that this study can determine the value of a variable and test the truth of the effect of preventive maintenance and breakdown maintenance on the achievement of production partially and simultaneously. Research subjects conducted in the Food Seasoning Industry. The population in this study were all employees in the maintenance and production divisions totaling 100 people. According to Suharsimi (2013), if the population is less than 100 people then the number of samples is sufficient to be taken as a whole, but if the population is greater than or equal to 100 people, then $10-15 \%$ or 20 $25 \%$ of the total population can be taken (Suharsimi, 2013). This study used a sample of $25 \%$ of the population. The sample selection is because the population is equal to 100 people. Based on the theory that the number of samples taken is 25 people. Intake is based on respondents who are experts in their fields.

The independent variables in this study are Preventive Maintenance $\left(\mathrm{X}_{1}\right)$ and Breakdown Maintenance $\left(\mathrm{X}_{2}\right)$ while the dependent variable is Production Achievement $(\mathrm{Y})$. All variables used in this study used a Likert scale (values 1 to 5) where respondents' answers were scored as follows: strongly agree with value 5 , agree with value 4 , disagree with value 3 , less disagree with value 2 and strongly disagree with value 1 . This study analyzed the truth test with the linear regression method. The test is carried out partially and simultaneously by testing 3 hypotheses. The following conceptual model can be seen in Figure 1. 
$\mathrm{H}_{1}$ : Partially there is the effect of preventive maintenance on production achievement

$\mathrm{H}_{2}$ : Partially there is an effect of breakdown maintenance on production achievement

$\mathrm{H}_{3}$ : Simultaneously there is the effect of preventive maintenance and breakdown maintenance on production achievement
Operational variables in this study used several supporting indicators to be analyzed. The following operational variables used can be seen in Table 1 and the conceptual model can be seen in Figure 2.

Table 1. Operational variable

\begin{tabular}{|c|c|c|c|c|}
\hline No & Variable & Variable Concept & Indicators & Reference \\
\hline 1 & $\begin{array}{l}\text { Preventive } \\
\text { Maintenance } \\
\left(\mathrm{X}_{1}\right)\end{array}$ & $\begin{array}{l}\text { Preventive Maintenance is a } \\
\text { maintenance model that is } \\
\text { carried out based on a } \\
\text { predetermined plan at a } \\
\text { certain time interval and is } \\
\text { preventive against the } \\
\text { occurrence of damage that } \\
\text { may occur. } \\
\text { (Sudrajat, 2011) }\end{array}$ & $\begin{array}{l}\text { 1. Maintain the reliability of the machine } \\
\text { and keep the machine in a healthy } \\
\text { condition. } \\
\text { 2. Reduce production defects } \\
\text { 3. Reduce downtime } \\
\text { 4. Support smooth production } \\
\text { 5. Maximize production results. }\end{array}$ & $\begin{array}{l}\text { Sudrajat } \\
(2011)\end{array}$ \\
\hline 2 & $\begin{array}{l}\text { Breakdown } \\
\text { Maintenance } \\
\left(\mathrm{X}_{2}\right)\end{array}$ & $\begin{array}{l}\text { Breakdown Maintenance } \\
\text { can be interpreted as a } \\
\text { maintenance policy through } \\
\text { a machine or equipment } \\
\text { operated until it is damaged, } \\
\text { then it is repaired or } \\
\text { replaced. } \\
\text { (Sudrajat, 2011) }\end{array}$ & $\begin{array}{l}\text { 1. Breakdown Maintenance is carried out } \\
\text { due to engine damage } \\
\text { 2. BM is carried out due to the decrease in } \\
\text { production achievement } \\
\text { 3. Blocking the production process } \\
\text { 4. Resulting in loss } \\
\text { 5. Occurs due to lack of attention to the } \\
\text { machine. }\end{array}$ & $\begin{array}{l}\text { Sudrajat } \\
(2011)\end{array}$ \\
\hline 3 & $\begin{array}{l}\text { Production } \\
\text { Achievement } \\
\text { (Y) }\end{array}$ & $\begin{array}{l}\text { Production output is the } \\
\text { result of the activity of } \\
\text { processing raw materials, } \\
\text { both in the form of raw } \\
\text { materials and semi-finished } \\
\text { materials into an item that } \\
\text { has a certain use-value. } \\
\text { Heizer and Render (2014) } \\
\text { (Heizer \& Barry, 2014) }\end{array}$ & $\begin{array}{l}\text { 1. Guaranteed smooth production if } \\
\text { preventive maintenance goes well } \\
\text { 2. Production yields increase if preventive } \\
\text { maintenance goes well. } \\
\text { 3. The production target is achieved if the } \\
\text { production machine works optimally. } \\
\text { 4. Production achievement decreases if } \\
\text { breakdown maintenance occurs } \\
\text { frequently. } \\
\text { 5. Production results decrease if } \\
\text { preventive maintenance is not optimal. }\end{array}$ & $\begin{array}{l}\text { Assauri } \\
(2011)\end{array}$ \\
\hline
\end{tabular}

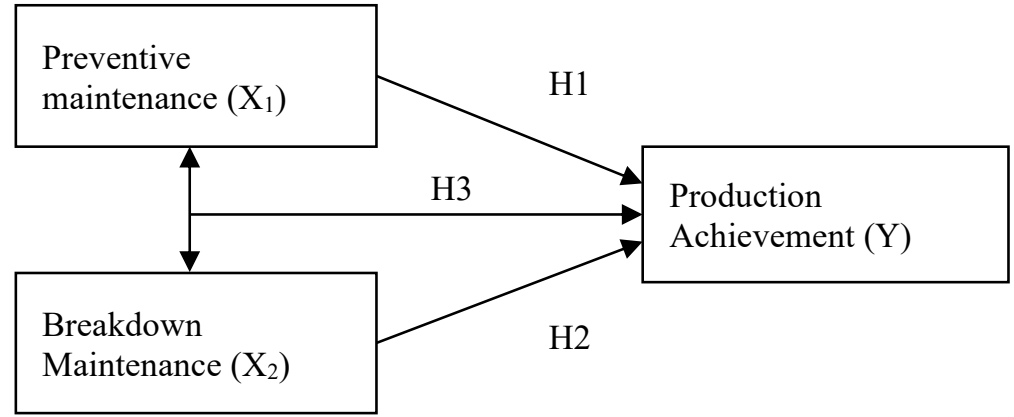

Figure 2. Conceptual model 


\section{RESULT AND DISCUSSION}

\subsection{Characteristics of Respondent}

In this study, sampling was carried out on 25 respondents from expert judgment. The selection of respondents is based on those who are experts in their fields. Characteristics of respondent in this study can be seen in Table 2.

Table 2. Characteristics of respondent

\begin{tabular}{llll}
\hline No & Characteristic & Details & $\begin{array}{l}\text { Amount of } \\
\text { respondent }\end{array}$ \\
\hline \multirow{3}{*}{1} & Respondent's & $25-30$ & 2 persons \\
& age & $30-40$ & 6 persons \\
& & $>40$ & 14 persons \\
2 & \multirow{2}{*}{ Gender } & Men's & 25 persons \\
& & Senior High & 22 persons \\
3 & \multirow{2}{*}{ Degree } & School & \\
& & Diploma 3 & 1 person \\
& & Bachelor & 2 persons \\
\hline
\end{tabular}

Based on Table 2, it can be seen that of the 25 respondents, 2 respondents aged $<25$ years, 6 people aged $25-30$ years, 14 people aged 30 40 years and $>40$ years old were 3 people. It can be interpreted that the age of $30-40$ years is a very large proportion. In addition, it can also be seen that from 25 respondents, the largest number of samples were men as many as 25 people or $100 \%$ of the respondents. It can be interpreted that the male gender is a very large proportion. Based on the education level group, the respondents have Bachelor's degrees as many as 2 people, 1 person with Diploma education and 22 people with Senior High School education or equivalent. It can be interpreted that having a senior high school education or equivalent is the largest proportion.

\subsection{Validity Test}

Testing the validity of each question item in this study was carried out by connecting the score of each item with the total score. To test whether each indicator is valid or invalid, by comparing the $r_{\text {count }}$ with the results of the $r$ table calculation. If $r_{\text {count }}>r$ table and is positive then the indicator is declared valid. Based on the number of samples as many as 25 respondents at a significance level of $5 \%(0.05)$ then $\mathrm{df}=\mathrm{n}-1$ $(25-1=24)$, the value of $r$ table for $\mathrm{df}=24$ is 0.397 . In the calculation of the validity test if the Significant value $(\mathrm{Sig})<0.05=$ Valid and if the Significant value $(\mathrm{Sig})>0.05=$ Invalid. The following results of the validity analysis can be seen in Table 3.

Table 3. Result of validity test

\begin{tabular}{cccccc}
\hline No & Indicators & R-value & R table & Significance (Sig) & Remark \\
\hline 1 & X1.1 & 0.701 & 0.396 & 0,000 & Valid \\
2 & X1.2 & 0.612 & 0.396 & 0,001 & Valid \\
3 & X1.3 & 0.677 & 0.396 & 0,000 & Valid \\
4 & X1.4 & 0.627 & 0.396 & 0,001 & Valid \\
5 & X1.5 & 0.662 & 0.396 & 0,000 & Valid \\
6 & X2.1 & 0.693 & 0.396 & 0,000 & Valid \\
7 & X2.2 & 0.857 & 0.396 & 0,000 & Valid \\
8 & X2.3 & 0.864 & 0.396 & 0,000 & Valid \\
9 & X2.4 & 0.783 & 0.396 & 0,000 & Valid \\
10 & X2.5 & 0.752 & 0.396 & 0,000 & Valid \\
\hline No & Indicators & R-value & R table & Significance (Sig) & Valid \\
\hline 11 & Y.1 & 0.596 & 0.396 & 0,020 & Valid \\
12 & Y.2 & 0.476 & 0.396 & 0,016 & Valid \\
13 & Y.3 & 0.467 & 0.396 & 0,019 & Valid \\
14 & Y.4 & 0.782 & 0.396 & 0,000 & Valid \\
15 & Y.5 & 0.850 & 0.396 & 0,000 &
\end{tabular}

Table 3 explains that all the calculated $r_{\text {values }}$ of the question items in the questionnaire are greater than the $r$ table values, meaning that all question items on the variable preventive maintenance $\left(\mathrm{X}_{1}\right)$, breakdown maintenance $\left(\mathrm{X}_{2}\right)$ and production achievement $(\mathrm{Y})$ are valid. 


\subsection{Reliability Test}

Reliability test was conducted to assess the consistency of the research instrument. An instrument research variable is said to be reliable if the Cronbach's Alpha value is greater than the standard test $(\alpha) 0.70$. The following results of the reliability analysis can be seen in Table 4 .

Table 4. Result of reliability test

\begin{tabular}{ccccc}
\hline No & Indicators & Cronbach's Alpha & Standard Value & Remark \\
\hline 1 & X1.1 & 0.861 & 0,60 & Reliable \\
2 & X1.2 & 0.878 & 0,60 & Reliable \\
3 & X1.3 & 0.860 & 0,60 & Reliable \\
4 & X1.4 & 0.878 & 0,60 & Reliable \\
5 & X1.5 & 0.860 & 0,60 & Reliable \\
6 & X2.1 & 0.865 & 0,60 & Reliable \\
7 & X2.2 & 0.860 & 0,60 & Reliable \\
8 & X2.3 & 0.862 & 0,60 & Reliable \\
9 & X2.4 & 0.864 & 0,60 & Reliable \\
10 & X2.5 & 0.860 & 0,60 & Reliable \\
11 & Y.1 & 0.875 & 0,60 & Reliable \\
12 & Y.2 & 0.878 & 0,60 & Reliable \\
13 & Y.3 & 0.886 & 0,60 & Reliable \\
14 & Y.4 & 0.864 & 0,60 & Reliable \\
15 & Y.5 & 0.860 & 0,60 & Reliable \\
\hline
\end{tabular}

Table 4 explains that all variables in this study are reliable, this can be seen from the value of Cronbach's alpha for the variable preventive maintenance $\left(\mathrm{X}_{1}\right)$, breakdown maintenance $\left(\mathrm{X}_{2}\right)$ and production achievement $(\mathrm{Y})$ is greater 0.70

\subsection{Linear Regression Analysis}

To find out whether there is a relationship between the variables of preventive maintenance, breakdown maintenance and production achievement and to measure the strength of the relationship, regression analysis is used with the calculation of SPSS version 21.00. The following processing results in the partial test can be seen in Table 5 and Table 6 .

\section{H1: Partially there is an effect of preventive maintenance on production output}

Based on the results of calculations from Table 5, the results of the calculated $t$ value of the preventive maintenance variable $\left(\mathrm{X}_{1}\right)$ are 2.453 and while the $\mathrm{t}_{\text {table }}$ is at a significance level of (a) $5 \%$ with $\mathrm{df}=25-1=24$ is 0.3297 . The preventive maintenance variable has a positive and significant effect on production output $(\mathrm{Y})$ this can be seen from the significance value $(0.000)$ less than 0.05 and $t_{\text {count }} 9.013>t_{\text {table }} 0.3297$. This means that if the preventive maintenance variable is increased, the production output will increase.

H2: Partially there is an effect of breakdown maintenance on production output.

Based on the results of calculations from Table 6 , the results of the calculated $t_{\text {value }}$ of the breakdown maintenance variable $\left(\mathrm{X}_{2}\right)$ are -7.926 while the $t_{\text {table }}$ at a significance level of (a) 5\% with $\mathrm{df}=25-1=24$ is 0.3297 . The breakdown maintenance variable has negative and significant effect on production output $(\mathrm{Y})$, this can be seen from the significance value $(0.000)$ less than 0.05 and $t$ count $-7.926>t$ table 0.3297 . This means that the greater the breakdown maintenance cost, the smaller the production achievement.

H3: Simultaneously there is the effect of preventive maintenance and breakdown maintenance on production output.

Based on the results of calculations from Table 7, the results of the calculated $f$ value for preventive maintenance $\left(\mathrm{X}_{1}\right)$ and breakdown maintenance $\left(\mathrm{X}_{2}\right)$ variables are 6.255 , while $\mathrm{f}$ table at a significance level of $(\alpha) 5 \%$ with $\mathrm{df}=$ $25-1=24$ is 4.279 . Preventive maintenance $\left(\mathrm{X}_{1}\right)$ and breakdown maintenance $\left(\mathrm{X}_{2}\right)$ variables have 
Table 5. The results of the partial test of preventive maintenance variable

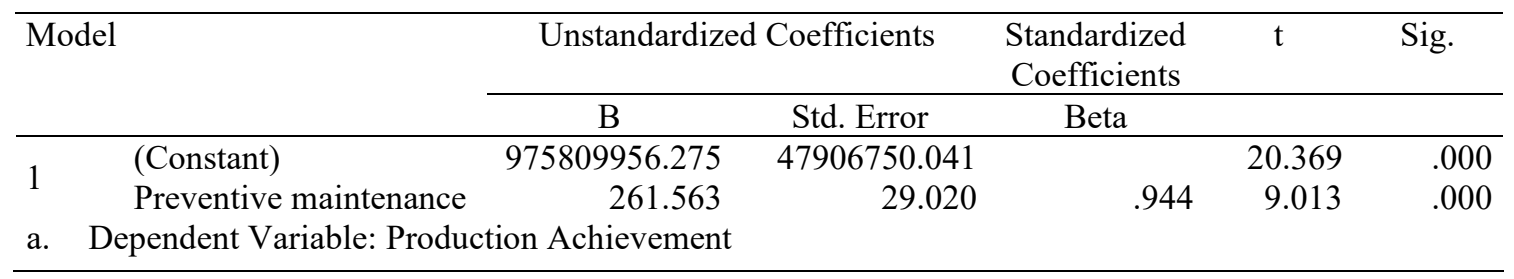

Table 6. The results of the partial test of breakdown maintenance variable

\begin{tabular}{|c|c|c|c|c|c|}
\hline \multirow[t]{2}{*}{ Model } & \multicolumn{2}{|c|}{ Unstandardized Coefficients } & \multirow{2}{*}{$\begin{array}{c}\begin{array}{c}\text { Standardized } \\
\text { Coefficients }\end{array} \\
\text { Beta } \\
\end{array}$} & \multirow[t]{2}{*}{$\mathrm{t}$} & \multirow[t]{2}{*}{ Sig. } \\
\hline & B & Std. Error & & & \\
\hline (Constant) & 1808755319.535 & 60073168.439 & & 30.109 & .000 \\
\hline Breakdown maintenance & -186.709 & 23.557 & -.929 & -7.926 & .000 \\
\hline a. Dependent Variable: Productio & Achievement & & & & \\
\hline
\end{tabular}

Table 7. Path coefficient (Model Summary)

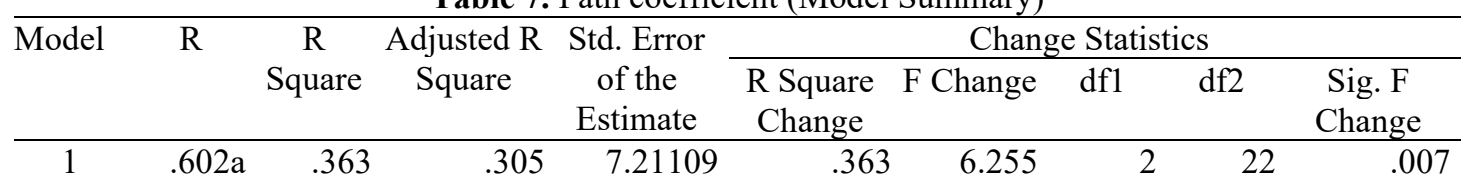

a. Predictors: (Constant), Breakdown Maintenance, Preventive Maintenance

Table 8. The results of the simultan test of preventive and breakdown maintenance variables

\begin{tabular}{|c|c|c|c|c|c|c|}
\hline \multirow[t]{2}{*}{ Model } & & \multicolumn{2}{|c|}{$\begin{array}{c}\text { Unstandardized } \\
\text { Coefficients }\end{array}$} & \multirow{2}{*}{$\begin{array}{c}\text { Standardized } \\
\text { Coefficients } \\
\text { Beta }\end{array}$} & \multirow[t]{2}{*}{$\mathrm{t}$} & \multirow[t]{2}{*}{ Sig. } \\
\hline & & $\mathrm{B}$ & Std. Error & & & \\
\hline \multirow{3}{*}{1} & (Constant) & 9.004 & 3.535 & & 2.547 & .018 \\
\hline & Preventive Maintenanace & .561 & .287 & .561 & 1.958 & .063 \\
\hline & Breakdown Maintenance & .042 & .237 & .050 & .175 & .862 \\
\hline
\end{tabular}

a. Dependent Variable: Production Achievement

a positive and significant effect on production output $(\mathrm{Y})$ this is evident from the significance value $(0.000)$ less than 0.05 and $\mathrm{f}_{\text {count }} 6.255>\mathrm{f}$ table 4.279. This means that both preventive maintenance and breakdown maintenance variables are increased, so production output will increase.

\subsection{Coefficient of Determination Test $\left(\mathbf{R}^{2}\right)$}

Based on the results of calculations with SPSS (can be seen Table 7), the $\mathrm{R}^{2}$ value in this study was $36.3 \%$, which means that the relationship is very close. Preventive maintenance and breakdown maintenance contributed $36.3 \%$ to production output. While the remaining $63.7 \%$ is explained by other reasons such as communication, leadership style and others.

Based on the result of the analysis in Table 8 , the multiple regression equation is obtained as follows: $\mathrm{Y}=9.004+0.561\left(\mathrm{X}_{1}\right)+0.042\left(\mathrm{X}_{2}\right)$

This value can be interpreted.

1. The coefficient of preventive maintenance $\left(\mathrm{X}_{1}\right)$ is $(+0.561)$ meaning that for every addition of 1 unit of value to preventive maintenance $\left(\mathrm{X}_{1}\right)$, it will increase the value of $\mathrm{Y}$ (production achievement) by 0.561 .

2. The coefficient of breakdown maintenance $\left(\mathrm{X}_{2}\right)$ is $(0.042)$ meaning that for every addition of 1 unit of value to breakdown maintenance $\left(\mathrm{X}_{2}\right)$, the value of $\mathrm{Y}$ (production achievement) will increase by 0.042 . 
3. A constant of 9,004 means that if $X_{1}$ and $X_{2}$ $=0$ then $\mathrm{Y}=9,004$.

\subsection{Discussion and Comparison of Results}

The relationship between Preventive Maintenance and Breakdown Maintenance on Production Achievement looks POSITIVE based on the Path Coefficient (R-value) of 0.363 . This is in line with previous research which (Iqbal, 2017) found that there is a strong and positive relationship between Preventive Maintenance and Breakdown Maintenance on Production Achievement simultaneously. However, there are differences in the partial test. The test results in this study have a NEGATIVE effect on Breakdown Maintenance on Production Achievement. This means that the greater the breakdown maintenance cost, the smaller the production achievement. This is proven in the problem phenomenon that the Breakdown Maintenance program costs are very large which makes production results not achieved.

\section{CONCLUSION}

Based on the results of data analysis and discussions that have been carried out in the previous chapter, the results obtained are that the preventive maintenance variable partially has a significant effect on production achievement. This means that if the performance of preventive maintenance is improved, it will affect or increase production achievement. The breakdown maintenance variable partially has a significant effect on the achievement of production. This means that the greater the breakdown maintenance cost, the smaller the production output. Variables preventive maintenance and breakdown maintenance simultaneously have a significant effect on the achievement of production. This means that these two variables together affect the increase in production output. This study obtained the value of the multiple regression equation, namely $\mathrm{Y}=9.004+0.561\left(\mathrm{X}_{1}\right)+0.042\left(\mathrm{X}_{2}\right)$.

This study only analyzes the independent and dependent variables, suggestions for future research are to deepen by analyzing the indicators of each of these variables using Structural Equation Modeling (SEM) based on covariance or Partial Least Square (PLS).

\section{REFERENCES}

Annasya. (2017). Mesin Farmasi: mesin Pin Mill. http://www.primabrt.com/2017/06/mesin-pin-mill.html. Accessed: 2021-09-25

Assauri, S. (2011). Manajemen Produksi dan Operasi (Pertama). Jakarta. LP FE UI.

Basri, E. I., Razak, I. H. A., Ab-Samat, H., \& Kamaruddin, S. (2017). Preventive Maintenance (PM) planning: a review. Journal of Quality in Maintenance Engineering, 23(2), 114-143. https://doi.org/https://doi.org/10.1108/JQ ME-04-2016-0014

Ben, J., Mohamed, A. O., \& Muduli, K. (2021). Effect of Preventive Maintenance on Machine Reliability in a Beverage Packaging Plant. International Journal of System Dynamics Applications, 10(3), 5066. https://doi.org/10.4018/ijsda.2021070104

Ebrahimi, M., Ghomi, S. M. T. F., \& Karimi, B. (2020). Application of the preventive maintenance scheduling to increase the equipment reliability: Case study-bag filters in cement factory. Journal of Industrial and Management Optimization, 16(1), 189-205. https://doi.org/10.3934/jimo.2018146

Er-Ratby, M., \& Mabrouki, M. (2018). Optimization of the Maintenance and Productivity of Industrial Organization. International Journal of Applied Engineering Research, 13(8), 6315-6324. https://doi.org/https://www.ripublication.c om/Volume/ijaerv13n8.htm

Heizer, J., \& Barry, R. (2014). Operation Management Sustainability and Suplly Chain Management (11th ed.). New York. McGraw-Hil.

Iqbal, M. (2017). Pengaruh Preventive Maintenance (Pemeliharaan Pencegahan) Dan Breakdown Maintenance (Penggantian Komponen Mesin) Terhadap Kelancaran Proses Produksi di PT.Quarryndo Bukit Barokah. Jurnal Manajemen Dan Bisnis (ALMANA), 17(3), 321-330.

https://doi.org/http://journal.unla.ac.id/ind ex.php/almana/article/view/394 
Irawan, B., Muttaqin, I., \& Maulana, Y. (2021). Pengaruh Preventive Maintenance Unit Pumping MF420EX Terhadap Hasil Produksi di PT. Kalimantan Prima Persada. Jurnal JIEOM, 04(01), 1-4. https://doi.org/http://dx.doi.org/10.31602/j ieom.v4i1.5324

Jasasila. (2017). Peningkatan Mutu Pemeliharaan Mesin Pengaruhnya Terhadap Proses Produksi Pada PT. Aneka Bumi Pratama. Jurnal Ilmiah Universitas Batanghari Jambi, 17(3), 96-102. https://doi.org/http://dx.doi.org/10.33087/j iubj.v17i3.405

Kumar, S., \& Yogish, H. (2016). Preventive Maintenance and Breakdown Reduction of Critical Machines. International Research Journal of Engineering and Technology, 03(06), 2632-2638. https://doi.org/https://www.irjet.net/volum e3-issue6

Liu, H., \& Wu, J. (2018). Research on Preventive Maintenance Strategy of Elevator Equipment. Open Journal of Social Sciences, 06(01), 165-174. https://doi.org/10.4236/jss.2018.61012

M.Méndez, J. D., \& Rodriguez, R. S. (2017). Total productive maintenance (TPM) as a tool for improving productivity: a case study of application in the bottleneck of an auto-parts machining line. International Journal of Advanced Manufacturing Technology, 92(1-4), 1013-1026. https://doi.org/10.1007/s00170-017-00524

Mohideen, A., \& Ramachandran, M. (2014). Strategic approach to breakdown maintenance on construction plant - UAE perspective. Benchmarking, 21(2), 226252. https://doi.org/10.1108/BIJ-05-20120030

Nursubiyantoro, E., Puryani, \& Rozaq, M. I. (2016). Implementasi Total Productive Maintenance (TPM) Dalam Penerapan Overall Equipment. Jurnal Opsi, 9(1), 24 32.

Prabowo, H. A., \& Adesta, E. Y. T. (2019). A study of total productive maintenance (TPM) and lean manufacturing tools and their impact on manufacturing performance. International Journal of
Recent Technology and Engineering, 7(6), 39-43.

Prabowo, H. A., Suprapto, Y. B., \& Farida, F. (2018). The Evaluation of Eight Pillars Total Productive Maintenance (TPM) Implementation and Their Impact on Overall Equipment Effectiveness (OEE) and Waste. Sinergi, 22(1), 13. https://doi.org/10.22441/sinergi.2018.1.00 3

Putri, N. T., Taufik, \& Buana, F. S. (2020). Preventive Maintenance Scheduling by Modularity Design Applied to Limestone Crusher Machine. Procedia Manufacturing, 43(2019), 682-687. https://doi.org/10.1016/j.promfg.2020.02. 123

Rizlan, W., Purba, H. H., Nasir, M., \& Aisyah, S. (2018). The effect of efficiency measurement to the improvement of maintenance productivity. International Journal of Engineering \& Technology, 7(4), 6964-6969. https://doi.org/10.14419/ijet.v7i4.23255

Sahrupi, S., \& Juriantoro, J. (2018). Usulan Penerapan Total Productive Maintenance pada Transfer Conveyor 17A. Jurnal Sistem Dan Manajemen Industri, 2(1), 51. https://doi.org/10.30656/jsmi.v2i1.568

Sari, N. K., \& Soepardi, A. (2018). Penjadwalan Kegiatan Pemeliharaan Untuk Memaksimalkan Availabilitas Mesin. Jurnal Opsi, 11(2), 105-111.

Sasitharan, D., Lazim, H. M., Lamsali, H., Iteng, R., \& Osman, W. N. (2020). The impact of preventive maintenance practices on malaysian manufacturing performance. International Journal of Supply Chain Management, $\quad 9(3), \quad$ 100-104. https://doi.org/https://ojs.excelingtech.co. uk/index.php/IJSCM/article/view/4845

Setiawan, I. (2021). Integration of Total Productive Maintenance and Industry 4.0 to increase the productivity of $\mathrm{NC}$ Bore machines in the Musical Instrument Industry. Proceedings of the 11th Annual International Conference on Industrial Engineering and Operations Management Singapore, 4701-4711.

Shagluf, A., \& Longstaff, A. P. (2014). Maintenance strategies to reduce 
downtime due to machine positional errors. Proceedings of Maintenance Performance Measurement and Management (MPMM) Conference 2014, 111-118. https://doi.org/http://dx.doi.org/10.14195/ 978-972-8954-42-0_16

Situmorang, V., Sutrisno, N., \& Pramulanto, H. (2020). Pengaruh Total Productive Maintenance (TPM) Terhadap Kelancaran Produksi Perusahaan PT. NGK Ceramics Indonesia. Jurnal Mitra Manajemen, 5(6), 357-371. https://doi.org/http://www.ejurnalmitramanajemen.com/index.php/jm $\mathrm{m} /$ article/view/538

Sudrajat, A. (2011). Pedoman Praktis Manajemen Perawatan Mesin Industri (1st ed.). Bandung. Refika Aditama.

Sugiyono. (2017). Metode Penelitian Kuantitatif, Kualitatif, dan $R \& D$ (1st ed.). Bandung. CV Alfabeta.
Suharsimi, A. (2013). Prosedur Penelitian: Suatu Pendekatan Praktek (1st ed.). Bandung. Rineka Cipta.

Sukma, D. I., Setiawan, I., \& Purba, H. H. (2021). A Systematic Literature Review of Overall Equipment Efectiveness Implementation in Asia. Journal of Industrial \& Quality Engineering, 9(1), 109-117.

https://doi.org/10.34010/iqe.v9i1.4015

Wang, N., Ren, S., Liu, Y., Yang, M., Wang, J., \& Huisingh, D. (2020). An active preventive maintenance approach of complex equipment based on a novel product-service system operation mode. Journal of Cleaner Production, 277(20), $1-17$.

https://doi.org/10.1016/j.jclepro.2020.123 365 